\title{
Hubungan Penjadwalan Dinas Perawat dengan Kepuasan Kerja Perawat di Instalasi Rawat Inap
}

\author{
Laila Rahmaniah1, Ichsan Rizany², Herry Setiawan³
}

1,2,3 Program Studi Ilmu Keperawatan, Fakultas Kedokteran, Universitas Lambung Mangkurat

\begin{tabular}{|c|c|}
\hline Article Info & Abstract \\
\hline $\begin{array}{l}\text { Article History: } \\
\text { Diterima } 27 \text { Mei } 2020 \\
\text { Key words: } \\
\text { Penjadwalan perawat; } \\
\text { Perawat; Kepuasan perawat }\end{array}$ & $\begin{array}{l}\text { Kepuasan kerja perawat di Rumah Sakit Idaman Banjarbaru masih rendah. } \\
\text { Salah satu faktor yang mempengaruhi kepuasan kerja adalah penjadwalan. } \\
\text { Penelitian ini bertujuan untuk mengetahui hubungan penjadwalan layanan } \\
\text { keperawatan dengan kepuasan kerja perawat di Rumah. Metode penelitian } \\
\text { ini menggunakan non-eksperimen dengan pendekatan cross-sectional. } \\
\text { Subjek penelitian ini adalah } 91 \text { pelaksana perawat di instalasi layanan rawat } \\
\text { inap di Rumah Sakit Idaman Banjarbaru, yang didapatkan melalui stratified } \\
\text { random sampling. Hasil penelitian menemukan bahwa terdapat hubungan } \\
\text { positif antara penjadwalan layanan keperawatan dengan kepuasan kerja } \\
\text { perawat di Rumah Sakit Idaman Banjarbaru (p-value =0,008; } r=0,274) \text {. } \\
\text { Jadwal layanan keperawatan dapat memengaruhi kepuasan kerja perawat. } \\
\text { Nilai penjadwalan layanan keperawatan masih rendah, sedangkan kepuasan } \\
\text { kerja perawat tidak mencapai standar minimum. Penjadwalan layanan } \\
\text { keperawatan yang baik dapat meningkatkan kepuasan kerja perawat. }\end{array}$ \\
\hline
\end{tabular}

\section{PENDAHULUAN}

Rumah sakit adalah sebuah tempat yang memberikan bantuan atau jasa terkait layanan kesehatan yang dilihat berdasarkan visi misi dan tujuan yang sudah ditetapkan bersama. Kinerja layanan tercermin dari sikap dan kualitas pemberi layanan, hal ini dapat dilihat salah satunya dari perawat (Winasih, Nursalam, \& Kurniawati, 2015). Perawat adalah individu yang memiliki pengaruh dalam berdirinya rumah sakit. Perawat dalam bekerja harus terampil dan kompeten sesuai dengan tindakan yang dilakukan, dari hal tersebut diharapkan perawat mendapatkan kepuasan kerja. Kepuasan kerja direfleksikan ketika individu senang dengan pekerjaannya (Wolo, Trisnawati, \& Wiyadi, 2015).

Kepuasan kerja adalah suatu rasa yang disukai dan tidak disukai saat karyawan menilai pekerjaannya (Bataha, 2019). Kepuasan kerja mempunyai dampak positif yang bermakna dengan kinerja karyawan, kinerja karyawan juga memiliki dampak positif terkait kepuasan pelanggan (Diliyanti, Parwita, \& Gama, 2018). Perawat yang tidak mempunyai kepuasan kerja cenderung tidak bisa mencapai kematangan psikologis dan perawat akan sering kali merasa keberatan terkait pekerjaan yang dikerjakan (Dewi, Aisyah, \& Siti, 2018). Terdapat beberapa faktor yang akan

Corresponding author:

Ichsan Rizany

ichsan.r.psik@ulm.ac.id

Jurnal Kepemimpinan dan Manajemen Keperawatan, Vol 3 No 1, Mei 2020

DOI: http://dx.doi.org/10.26594/jkmk.v3.i1.554

e-ISSN 2621-5047 
mempengaruhi kepuasan perawat yaitu karakteristik individu (termasuk umur, pengalaman kerja, tingkat pendidikan, dan jenis kelamin), gaji, lingkungan kerja, kondisi kerja, reward, dukungan, dan penjadwalan (Rizany, Hariyati, Afifah, \& Rusdiyansyah, 2019).

Berdasarkan hasil penelitian (Rhona Sandra, 2017) mengenai kepuasan kerja perawat di RSUD Solok Tahun 2016 $(51,6 \%)$ menyatakan puas. Penelitian (Daniyanti \& Kamil, 2016) tentang kepuasan kerja perawat pelaksana berada pada kategori kurang puas $(57,5 \%)$. Sedangkan pada penelitian (Kundre, 2018) untuk kepuasan kerja di Rumah Sakit GMIM Pancaran Kasih Manado Tahun 2017 menunjukan data sebanyak 23 responden (60.5\%) yang merasa tidak puas, dan 15 responden (39.5\%) yang merasa puas. Berdasarkan hasil penelitian (Rizany et al., 2019) tingkat kepuasan perawat adalah 67,11 (67\%). Data kepuasan kerja perawat di Instalasi Rawat Inap RSD Idaman Kota Banjarbaru pada tahun 2018 sebesar 73,1\% puas dan $17 \%$ tidak puas dikarenakan gaji, pemberian insentif tambahan atas prestasi atau kerja ekstra, ketersedian peralatan perlengkapan yang mendukung pelayanan, dan kesempatan untuk meningkatkan kemampuan kerja melalui pelatihan serta perhatian institusi rumah sakit terhadap perawat.

Penjadwalan perawat merupakan sebuah hal yang memberikan pengaruh karena memiliki keterikatan antara tingkat keahlian yang dimiliki dan kepasitas atau kompetensi yang ada pada diri perawat untuk pemberian pelayanan perawatan kepada pasien. Jadwal perawat yang kerap berubah dan tidak sesuai dengan kapasitas akan berakibat negatif saat keadaan pasien memburuk dan darurat, semangat staf bekerja akan turun (Clark, Moule, Topping, \& Serpell, 2015). Penjadwalan adalah tata kelola jam untuk mengerjakan semua pekerjaan agar terselesaikannya semua aktivitas demi mencapai target secara maksimal dengan tidak lupa memperhatikan keterbatasan-keterbatasan yang ada (Rahman, Mulyani, \& Rizany, 2018).

Penjadwalan perawat di Indonesia salah satunya dikategorikan dalam bentuk pola penjadwalan dinas jaga atau shift, yaitu dinas jaga pagi, dinas jaga sore, dan dinas jaga malam (Susandi \& Milana, 2015). Namun pengkategorian dinas jaga ini kadang bukan menjadi jalan keluar mengenai lamanya keberlangsungan kegiatan perawat di ruang rawat inap. Dinas jaga yang dibuat terkadang cuma memikirkan aturan-aturan yang ada di rumah sakit, tidak mempertimbangkan keinginan perawat. Hal ini setidaknya akan berdampak mengenai kreativitas perawat dan akan berdampak juga terhadap produksi rumah sakit itu sendiri (Sri Marhaini, 2018).

Berdasarkan studi pendahuluan yang dilakukan peneliti dari hasil wawancara yang dilakukan dengan kepala ruangan, untuk pembagian jadwal dinas sesuai standar prosedur operasional terdiri dari shift pagi jam 07.30-14.30 WITA, shift siang jam 14.30-21.30 WITA, dan shift malam 21.30-07.30 WITA dengan pembagian pola dinas yaitu pagi, siang, malam, lepas dinas dan libur, untuk pembagian jadwal dinas terkendala jumlah anggota diruangan sehingga kepala ruangan kesulitan berbuat adil dalam pembagian jadwal dinas. Sedangkan berdasarkan hasil wawancara dengan perawat diruangan setiap 2 bulan sekali terjadi perombakan jadwal dinas, saat 1 minggu pertama jadwal dinas sering terjadi kekacauan, kurangnya jumlah anggota dalam tim yaitu berjumlah 2 orang yang seharusnya 4 orang sedangkan jumlah pasien banyak, sehingga perawat merasa kelelahan dengan pembagian jadwal dinas, dan dari wawancara konflik merupakan sesuatu hal yang pasti ada saat bekerja. Tujuan penelitian ini adalah untuk menganalisis hubungan penjadwalan dinas perawat dengan kepuasan kerja perawat di instalasi rawat inap. 


\section{METODE}

Desain penelitian yang dipakai adalah cross sectional. Pupulasi dalam penelitian berjumlah 103 perawat pelaksana di instalasi rawat inap RSD Idaman Kota Banjarbaru. Teknik yang digunakan yaitu stratified random sampling. Sampel pada penelitian dihitung menggunakan rumus slogan sehingga didapatkan 91 perawat sesuai kriteria inklusi. Sampel diambil dari 6 ruangan di instalasi rawat inap meliputi ruang Nuri, Cendrawasih, Kasuari, VIP Murai, Merak dan Camar. Kriteria inklusi yaitu perawat pelaksana yang bekerja di ruang rawat inap RSD Idaman Kota Banjarbaru, responden penelitian bersedia sebagai responden, perawat yang bukan orientasi dan menetap 1 bulan di RS, dan perawat ruangan minimal berpendidikan DIII Keperawatan.

Instrumen yang dipakai pada penelitian adalah kuesioner penjadwalan dinas perawat serta kuesioner kepuasan kerja perawat. Kuesioner penjadwalan dinas perawat merupakan instrumen manajemen penjadwalan dinas yang diperoleh dari penelitian (Rizany et al., 2019) yang diambil dari (NHS, 2016) dan (Marquis, BL \& Huston, 2012) dengan nilai validitas kuesioner yaitu 0,361 dan untuk uji reliabilitas item dengan skala Guttman dengan alpha $=0,701$, sedangkan skala tipe Likert dengan alpha $=0,900$. Kuesioner kepuasan kerja perawat di ambil dari Hariyati, et al dalam Program Jenjang Karier JICA- Kementerian Kesehatan RI, 2013). Instrumen ini memiliki nilai validitas 0,56 0,83 dan reabilitas sebesar 0,91 dan sudah baku sehingga tidak perlu lagi dilakukan uji validitas dan reliabilitas.

Analisis data yang digunakan yaitu uji korelasi spearman. Prinsip etik yang diperhatikan dalam penelitian adalah lembar persetujuan responden, tanpa nama, kerahasiaan, hak untuk menolak dan berbuat baik. Penelitian ini telah dinyatakan layak etik dari Fakultas Kedokteran
Universitas Lambung Mangkurat dengan No.605/KEPK-FK UNLAM/EC/XII/19.

\section{HASIL}

Karakteristik responden diidentifikasi berdasarkan usia, masa kerja, dan penghasilan. Untuk usia pada penelitian ini didapatkan rata-rata usia responden adalah 29,89 tahun dengan usia paling muda responden adalah 23 tahun dan usia paling tua responden adalah 42 tahun. Kategori usia responden ini termasuk usia muda dengan mempertimbangkan bahwa perawat yang usianya muda mempunyai produktivitas dan motivasi yang baik dalam bekerja dibandingkan dengan usia yang lanjut, tenaga muda memiliki keterampilan fisik dan keadaan kesehatan yang lebih baik dari usia lanjut, sehingga dapat menunjang produktivitas dalam bekerja.

Pada penelitian ini rata-rata masa kerja responden adalah 5,46 tahun dengan masa kerja terendah responden adalah 5 bulan dan masa kerja paling lama responden adalah 18 tahun. Peneliti berasumsi bahwa individu dengan masa kerja yang lama akan semakin professional dalam bekerja dan lebih pandai karena memiliki banyak pengalaman, sehingga dapat membimbing individu yang baru bekerja. Sehingga tujuan pekerjaan yang diberikan dapat di kerjakan secara efektif, efisien, baik dan benar sesuai dengan bidang yang dikerjakannya.

Rata-rata penghasilan responden adalah Rp. $\quad 1.972 .967$ dengan penghasilan responden paling rendah adalah $\mathrm{Rp}$. 1.210.000 dan penghasilan responden paling tinggi adalah Rp. 4.000.000. Penghasilan yang diperoleh adalah gaji yang menetap sebagai perawat di RSD Idaman Kota Banjarbaru. Adapun penghasilan yang didapat pada penelitian ini hanya berupa gaji pokok, belum ditambah pendapatan remunerasi dan insentif lainnya sebagai perawat di RSD Idaman Kota Banjarbaru. 
Tabel 1

Karakteristik responden menurut usia, masa kerja, dan penghasilan $(n=91)$

\begin{tabular}{lccc}
\hline \multicolumn{1}{c}{ Indikator } & Rata-rata & SD & Min-Max \\
\hline $\begin{array}{l}\text { Usia } \\
\text { (Tahun) }\end{array}$ & 29,89 & 4,884 & $23-42$ \\
\hline $\begin{array}{l}\text { Masa Kerja } \\
\text { (Tahun) }\end{array}$ & 5,46 & 4,563 & $0,5-18$ \\
\hline $\begin{array}{l}\text { Penghasilan } \\
\text { (Rp) }\end{array}$ & 1.972 .967 & 873,084 & $\begin{array}{c}1.210 .000- \\
4.000 .000\end{array}$ \\
\hline
\end{tabular}

Hasil penelitian menunjukkan bahwa jenis kelamin perawat didominasi oleh perempuan. Tingkat pendidikan responden yang paling banyak adalah DIII Keperawatan. Peneliti berpendapat bahwa pendidikan yang tinggi dapat meningkatkan karier dan kapasitas masing-masing individu, sehingga tingkat pendidikan perlu di tingkatkan agar kapasitas individu dapat merata sesuai dengan kompetensi yang dimiliki individu ketika bekerja. Pada penelitian ini jenjang karir perawat PK I lebih dominan dibandingkan yang lainnya dan peneliti berpendapat pentingnya peningkatan kompetensi perawat untuk peningkatan dalam pemberian layanan. Adapun beban kerja perawat klinis I seperti yang tercantum dalam PMK No 40 Tahun 2017 perawat klinis I mampu mengerjakan asuhan keperawatan dasar yang ditekankan pada bakat atau keahlian teknis yang dimiliki dan berada dibawah serta mendapat arahan keperawatan (Rizany, Sri Hariyati, \& Purwaningsih, 2017)

Pengelolaan jadwal dinas responden dalam penelitian ini menunjukkan bahwa pengelolaan jadwal dinas semuanya dibuat oleh kepala ruangan (desentralisasi) sebesar $91 \quad$ (100\%). Penjadwalan desentralisasi memberikan kemudahan staf untuk mampu mengendalikan lingkungan kerja, peningkatan otonomi perawat dalam penjadwalan dan fleksibilitas (Rizany et al., 2017). Rata-rata penjadwalan dinas perawat di instalasi rawat inap sebesar 70,63 (58,04\% dari 91) dengan nilai paling rendah 52 dan nilai paling tinggi 90 . Hasil tersebut dapat dikatakan bahwa penjadwalan dinas perawat di instalasi rawat inap masih kurang.

Berdasarkan distribusi jawaban responden diketahui bahwa parameter penjadwalan dinas perawat tertinggi yaitu pada parameter pertanyaan Fleksibilitas nomor 15 sebesar $3,31 \quad(77 \%$ dari skor total tertinggi). Parameter pertanyaan terendah pada parameter reward yaitu pertanyaan nomor 2 dan nomor 18 dengan nilai 2,37 $(9,25 \%)$.

Tabel 2

karakteristik responden menurut jenis kelamin, pendidikan, jenjang karir $(\mathrm{n}=91)$

\begin{tabular}{|c|c|c|}
\hline Indikator & $\mathrm{f}$ & $\%$ \\
\hline \multicolumn{3}{|l|}{ Jenis Kelamin } \\
\hline Laki-laki & 36 & 39,6 \\
\hline Perempuan & 55 & 60,4 \\
\hline \multicolumn{3}{|l|}{ Pendidikan } \\
\hline DIII Keperawatan & 59 & 64,8 \\
\hline DIII+S.Kep & 5 & 5,5 \\
\hline S.Kep+Ners & 27 & 29,7 \\
\hline \multicolumn{3}{|l|}{ Jenjang Karir } \\
\hline Pra PK & 8 & 8,8 \\
\hline PK I & 50 & 54,9 \\
\hline PK II & 23 & 25,3 \\
\hline PK III & 10 & 11,0 \\
\hline \multicolumn{3}{|l|}{ Pengelolaan Jadwal } \\
\hline Dinas & & \\
\hline $\begin{array}{l}\text { Kepala Bidang } \\
\text { Keperawatan } \\
\text { (sentralisasi) }\end{array}$ & 0 & 0 \\
\hline $\begin{array}{l}\text { Perawat } \\
\text { Scheduling) }\end{array}$ & 0 & 0 \\
\hline $\begin{array}{l}\text { Kepala Ruangan } \\
\text { (desentralisasi) }\end{array}$ & 91 & 100,0 \\
\hline
\end{tabular}

Hasil penelitian menjelaskan nilai rata-rata kepuasan kerja perawat di instalasi rawat inap RSD Idaman Kota Banjarbaru sebesar $61,97 \quad(52,46 \%$ dari 91) dengan nilai terendah 45 dan nilai tertinggi 87. Hasil ini membuktikan bahwa kepuasan kerja perawat tersebut masih belum mencapai standar kepuasan kerja perawat sebesar $90 \%$ berada dibawah minimum standar dan dibawah rata-rata Minnesota Satisfaction Quesioner (MSQ) yaitu 75,4 yang berarti kepuasan kerja perawat belum mencapai standar target yang ditentukan. 
Berdasarkan distribusi jawaban responden diketahui bahwa parameter kepuasan kerja perawat tertinggi terdapat pada parameter Activity (Aktivitas) pada pertanyaan nomor 1 dengan nilai sebesar 3,41 (60,25\%) dan paramater Social Service (Layanan Sosial) pada pertanyaan nomor 9 yaitu 3,61 (60,25\%). Parameter kepuasan kerja perawat terendah pada parameter pertanyaan Compensation (Kompensasi) nomor 16 dengan nilai 2,37 (34,25\%).

Hasil penelitian menunjukkan bahwa terdapat hubungan yang signifikan penjadwalan dinas dengan kepuasan kerja perawat dengan kekuatan hubungan sedang dan arah hubungan searah, yang berarti bahwa semakin baik penjadwalan dinas perawat maka semakin tinggi kepuasan kerja perawat di instalasi rawat inap sebaliknya semakin menurun penjadwalan dinas perawat maka semakin rendah kepuasan kerja perawat.

Tabel 3

Hubungan penjadwalan dinas perawat dengan kepuasan kerja perawat di instalasi rawat inap

\begin{tabular}{lcc}
\multicolumn{3}{c}{$(\mathrm{n}=91)$} \\
\multicolumn{1}{c}{ Indikator } & $\begin{array}{c}\text { Koefisien } \\
\text { Korelasi }\end{array}$ & $p$ \\
\hline $\begin{array}{l}\text { Hubungan penjadwalan } \\
\text { dinas perawat dengan } \\
\text { kepuasan kerja perawat }\end{array}$ & 0,274 & 0,008 \\
\hline
\end{tabular}

\section{PEMBAHASAN}

\section{Penjadwalan Dinas Perawat}

Berdasarkan hasil penelitian didapatkan bahwa penjadwalan dinas perawat di RSD Idaman Kota Banjarbaru masih kurang. Hasil penelitian ini apabila pada penelitian Penjadwalan Dinas Perawat di 3 RS Militer dengan rata-rata 95,59 jika dipersentasekan (81\% dari total nilai) yang mengarah ke cukup baik. Adapun pada penelitian penjadwalan dinas perawat berdasarkan persepsi pasien di ruang rawat inap RSUD Ulin Banjarmasin sebesar 37,29 (77,68\% dari 48) dapat dikatakan tinggi.
Berdasarkan parameter penjadwalan dinas perawat tertinggi yaitu pada parameter pertanyaan fleksibilitas 3,31 dengan persentase rata-rata (77\%) yaitu pada pertanyaan nomor 15 . Peneliti berasumsi bahwa penjadwalan dinas yang fleksibel akan membuat karyawan merasa nyaman dan jadwal dinas yang dibuat sebagai bentuk antisipasi terjadinya perubahanperubahan dengan pertimbangan dan membagi full time, part time, rotasi shift dan permanen shift. Jadwal yang fleksibel dirasakan perawat akan memberikan keseimbangan hidup bagi perawat salah satunya untuk mengambil istirahat dan meningkatkan kualitas pelayanan dan fleksibel ini sebagai sistem untuk menangani perubahan. Hasil penelitian ini apabila pada penelitian Penjadwalan Dinas Perawat di 3 RS Militer dengan rata-rata 95,59 jika dipersentasikan $(81 \%$ dari total nilai) yang mengarah ke cukup baik (Rizany et al., 2017).

Fleksibilitas jam kerja memiliki pengaruh kepada perawat dengan memberikan izin untuk perubahan atau modifikasi jadwal terkait kebutuhan yang tidak bisa ditinggalkan dan sudah mendesak, sehingga mengharuskan pertukaran jadwal antara perawat lain diruangan ketika bekerja. Pembagian jadwal yang adil akan memberikan dampak positif ketika dalam keperluan mendesak karyawan bisa mendapatkan haknya dan memiliki waktu yang banyak untuk keluarganya setelah beraktivitas bekerja dan memiliki waktu luang (Dwi \& Pradhanawati, 2018). Penjadwalan yang fleksibel diberikan kepada perawat untuk memenuhi haknya. Jadwal yang fleksibel akan memberikan kelangsungan kehidupan bagi perawat salah satunya memungkinkan perawat untuk mengambil istirahat untuk meningkatkan layanan secara optimal. Selain itu, manajemen jadwal dinas dengan shift dan hari off yang tepat memungkinkan perawat untuk mengambil istirahat untuk meningkatkan kualitas pelayanan (Leineweber et al., 2016). 
Fleksibilitas membuktikan bahwa dukungan bagi karyawan akan membantu meringankan kewajiban dalam organisasi yang dilakuan dengan cara mewujudkan sebagian besar hak karyawan dalam kehidupan mereka yang cenderung aktif. Beberapa karyawan akan memberikan timbal balik atas fleksibilitas yang dikerjakan dengan bentuk komitmen yang kuat terkait pekerjaannya dan ketersediaan ataupun penawaran yang fleksibel yang sudah ditetapkan dengan kebijakan kerja secara positif akan membuat komitmen karyawan menjadi lebih bagus (Sari, Murnita, FITRI, \& Wulandari, 2019).

\section{Kepuasan Kerja Perawat}

Berdasarkan hasil penelitian didapatkan hasil 61,97 dengan persentase rata-rata 52,46\%. Hasil ini membuktikan bahwa kepuasan kerja perawat tersebut masih belum mencapai standar kepuasan kerja perawat yang ditentukan oleh RSD Idaman Kota Banjarbaru sebesar $90 \%$ berada dibawah minimum standar dan dibawah rata-rata Minnesota Satisfaction Quesioner (MSQ) yaitu 75,4 yang berarti kepuasan kerja perawat belum mencapai standar target yang ditentukan. Penelitian ini sejalan dengan (Rahman, 2019) kepuasan kerja perawat dalam kategori rendah dengan mean 62,82 (64,44\%).

Berdasarkan parameter kepuasan kerja perawat terendah yaitu pada parameter pertanyaan Compensation (kompensasi) 2,37 dengan persentasi rata-rata $34,25 \%$ terdapat pada nomor 13. Peneliti berasumsi bahwa kompensasi yang didapatkan oleh perawat masih dibawah dan belum sesuai dengan yang diinginkan mereka sehingga dapat menyebabkan kurangnya motivasi dalam bekeraja. Hal yang mempengaruhi kepuasan salah satunya adalah kompensasi, keadilan kompensasi akan mengakibatkan timbulnya motivasi pada diri karyawan, kompensasi akan berdampak pada betah atau tidaknya karyawan dalam bekerja (Annur \& Martono, 2017).
Berbagai macam hal untuk menaikkan kepuasan dan prestasi kerja yaitu melalui kompensasi, kompensasi dalam bentuk finasial akan memenuhi kebutuhan karyawan secara langsung, terutama kebutuhan fisiologis. Perawat yang memiliki kompensasi sesuai dengan yang diinginkan akan bekerja lebih rajin dan merasa pekerjaannya dihargai. Sehingga semakin tinggi kompensasi maka akan meningkat kepuasan kerja perawat (Insan \& Yuniawan, 2016).

\section{Hubungan Penjadwalan Dinas Perawat dengan Kepuasan Kerja Perawat}

Penelitian yang dilakukan mendapatkan hasil bahwa ada Hubungan Penjadwalan Dinas Perawat dengan Kepuasan Kerja Perawat di Instalasi Rawat Inap RSD Idaman Kota Banjarbaru dengan kekuatan hubungan sedang. Penelitian ini mengarah ke hubungan positif yang berarti semakin baik penjadwalan dinas perawat maka semakin tinggi kepuasan kerja perawat di ruang rawat inap sebaliknya apabila semakin menurun penjadwalan dinas perawat maka semakin rendah kepuasan kerja perawat. Sejalan dengan penelitian terdahulu menyatakan ada hubungan yang signifikan antara implementasi penjadwalan dinas perawat di RS Militers (Rizany et al., 2019). Adapun pada pada penelitian lain mengatakan bahwa ada hubungan antara penjadwalan dinas perawat dengan tingkat kepuasan pasien di ruang rawat inap RSUD Ulin Banjarmasin (Rahman et al., 2018).

Kepuasan perawat salah satunya dipengaruhi oleh pengelolaan jadwal dinas. Apabila penjadwalan dinas perawat tidak optimal maka bisa berdampak terhadap kepuasan perawatan. Adapun terkait penelitian lainnya yang mempertegas bahwa penjadwalan dinas perawat dapat meningkatkan kepuasan kerja perawat (Al Maqbali, 2015). Selain penjadwalan dinas perawat terdapat komponen-komponen lain yang memiliki pengaruh terkait kepuasan kerja. Kepuasan kerja perawat 
dipengaruhi oleh pekerjaan itu sendiri dan suasana bekerja (Wolo et al., 2015). Selain itu kepuasan kerja dipengaruhi oleh imbalan dan motivasi (R., Tamsah, \& Kadir, 2016). Artinya ada faktor lain yang dapat memunculkan kepuasan kerja, adapun faktor-faktor yang berpengaruh tersebut yaitu pekerjaan itu sendiri, pembayaran, promosi, teman bekerja, motivasi, keseluruhan dan pengamatan (Robbin $\mathrm{S}$, 2015).

\section{SIMPULAN}

Hasil penelitian ini dapat disimpulkan bahwa ada hubungan penjadwalan dinas perawat dengan kepuasan kerja perawat.

\section{UCAPAN TERIMAKASIH}

Penulis mengucapkan terimakasih kepada responden yang telah ikut serta berpartisipasi dalam penelitian ini.

\section{REFERENSI}

Al Maqbali, M. A. (2015). Factors that influence nurses' job satisfaction: A literature review. Nursing Management, 22(2), 30-37. https://doi.org/10.7748/nm.22.2.30.e1297

Annur, M. F., \& Martono, S. (2017). Peningkatan Komitmen Organisasional Perawat melalui Kompensasi, Kepuasan Kerja dan Budaya Organisasi. Management Analysis Journal, 6.

Bataha, Y. (2019). Gaya Pemimpin Kepala Ruangan Dengan Kepuasaan Perawat. Gaya Pemimpin Kepala Ruangan Dengan Kepuasaan Perawat, $7(2)$.

Clark, A., Moule, P., Topping, A., \& Serpell, M. (2015). Rescheduling nursing shifts: Scoping the challenge and examining the potential of mathematical model based tools. Journal of Nursing Management, 23(4), 411-420. https://doi.org/10.1111/jonm.12158

Daniyanti, M., \& Kamil, H. (2016). Conflict Management and Job Satisfaction of the Nurses in the Public Hospital dr. Zainoel Abidin Banda Aceh. 1-7.

Dewi, Aisyah, A., \& Siti. (2018). Hubungan Lingkungan Kerja Fisik dengan Kepuasan Kerja Perawat di RSU Haji Medan. 1(2), 120-128.

Diliyanti, N. N., Parwita, G. B. S., \& Gama, G. (2018). Pengaruh Budaya Organisasi dan Kepuasan Kerja Terhadap Kinerja Perawat dan Bidan Di
Rumah Sakit Ibu dan Anak (RSIA) Puri Bunda Denpasar. Forum Manajemen, 16(1), 1-8.

Dwi, K., \& Pradhanawati, A. (2018). Pengaruh Peran Ganda, Fleksibilitas Jam Kerja Dan Gaji Terhadap Kesejahteraan Perawat Perempuan Pada Rumah Sakit Panti Wilasa Citarum Semarang. Ilmu Administrasi Bisnis, 5, 57-67.

Insan, P. D., \& Yuniawan, A. (2016). Pengaruh Gaya Kepemimpinan Partisipatif, Lingkungan Kerja, Kompensasi Dan Budaya Organisasi Terhadap Kinerja Karyawan (Studi Pada Bagian Keperawatan Rsud Tugurejo Semarang). Diponegoro Journal of Management, 5(1), 1-13.

Kundre, R. (2018). Hubungan Kepuasaan Kerja Perawat Dengan Pelaksanaan Pendokumentasian Keperawatan Di Rumah Sakit Gmim Pancaran Kasih Manado. Jurnal Keperawatan, 6(1).

Leineweber, C., Chungkham, H. S., Lindqvist, R., Westerlund, H., Runesdotter, S., Smeds Alenius, L., \& Tishelman, C. (2016). Nurses' practice environment and satisfaction with schedule flexibility is related to intention to leave due to dissatisfaction: A multi-country, multilevel study. International Journal of Nursing Studies, 58, 47-58. https://doi.org/10.1016/j.ijnurstu.2016.02.00 3

Marquis, BL \& Huston, C. (2012). Leadership Roles And Management Functions In Nursing : Theory And Application, Wolters Kluwer Health Lippincott Williams \& Wilkins,. Philadelphia.

Muhammad Rijali Rahman. (2019). Hubungan Gaya Kepemimpinan Kepala Ruangan dengan Kepuasan Kerja Perawat di Ruang Rawat Inap RSD Idaman Kota Banjarbaru. Universitas Lambung Mangkurat.

NHS. (2016). Good Practice Guide: Rostering Signature. June.

R., F., Tamsah, H., \& Kadir, I. (2016). Pengaruh Imbalan dan Motivasi terhadap Kepuasan Kerja Perawat Badan Layanan Umum (BLU) Pada Rumah Sakit Bhayangkara Makassar. Jurnal Mirai Manajement, Volume 1 Normor 2, 1, 14-23.

Rahman, S., Mulyani, Y., \& Rizany, I. (2018). Penjadwalan Dinas Perawat berhubungan dengan Kepuasan Pasien di Ruang Rawat Inap RSUD Ulin Banjarmasin. Dunia Keperawatan, 6(1),

41. https://doi.org/10.20527/dk.v6i1.5081

Rhona Sandra, D. S. (2017). Faktor-Faktor Yang Berhubungan Dengan Kepuasan Kerja Perawat Pelaksana Di Ruang Rawat Inap Rsud Solok. 15(3), 148-155.

Rizany, I., Hariyati, R. T. S., Afifah, E., \& Rusdiyansyah. (2019). The Impact of Nurse Scheduling 
Management on Nurses' Job Satisfaction in Army Hospital: A Cross-Sectional Research. SAGE Open, 9(2). https://doi.org/10.1177/2158244019856189

Rizany, I., Sri Hariyati, T., \& Purwaningsih, S. (2017). Optimalisasi Fungsi Kepala Ruangan Dalam Penetapan Jadwal Dinas Perawat Berbasis Kompetensi: Pilot Study. Jurnal Persatuan Perawat Nasional Indonesia (JPPNI), 1(3), 244. https://doi.org/10.32419/jppni.v1i3.35

Robbin S. (2015). Perilaku Organisai. Jakarta.

Sari, Murnita, D., FITRI, \& Wulandari. (2019). Pengaruh Fleksibilitas Jam Kerja Terhadap Kepuasan Kerja Dengan Komitmen Organisasi Dan Konflik Pekerjaan-Keluarga Sebagai Variabel Mediasi (Studi Pada Wanita Bekerja di Kota Surakarta). IAIN Surakarta.

Sri Marhaini. (2018). Penjadwalan Kerja Karyawan Di RSU Sari Mutiara Medan Dengan Aplikasi Pewarnaan Graf Menggunakan Algoritma Tabu Search. Universitas Negeri Medan.

Susandi, D., \& Milana, L. (2015). Perancangan Dan Pembuatan Aplikasi Penyusunan Jadwal Kerja Dinas Jaga Perawat IGD Menggunakan Algoritma TPB. Infotech Journal, 1(1), 236695.

Winasih, R., Nursalam, N., \& Kurniawati, N. D. (2015). Cultural Organization and Quality of Nursing Work Life on Nurses Performance and Job Satisfaction in Dr. Soetomo Hospital, Surabaya. Jurnal NERS, 10(2), 332. https://doi.org/10.20473/jn.v10i22015.332342

Wolo, P. D., Trisnawati, R., \& Wiyadi. (2015). Faktor Faktor Yang Mempengaruhi Kepuasan Kerja Perawat Pada RSUD TNI AU Yogyakarta. Jurnal Ekonomi Manajemen Sumber Daya, 17, 25-34. 